\title{
Desain Pembelajaran Keagamaan Islam Berbasis Neurosains
}

\author{
Saifurrahman ${ }^{1}$, Suyadi $^{2}$ \\ ${ }^{12}$ Universitas Ahmad Dahlan, Yogyakarta, Indonesia \\ Email: Saiful11411@gmail.com
}

\begin{abstract}
Learning is a stimulation for the development of thinking, but often learning is not designed according to the science of thinking or neuroscience. This article offers a fresh idea of how Islamic religious learning design is designed based on neuroscience. This study uses library research with a descriptive analytical approach to the themes of Neuroscience that can be applied in elementary school education and the results of the discussion of this article show that the design of Islamic religious learning can at least be done with three schemes; opening (fluorescent lighting, thought beats, challenging class settings etc.); Inti (sink setting/ ambak, expository, discussion, role play and assessment); Cover (enker and the like)
\end{abstract}

Keywords: Learning Design; Islamic religion; Based on Neuroscience

\section{Pendahuluan}

Dalam beberapa dasawarsa terahir kita sering banyak sekali kita mendengar krisis dibidang pembelajaran keagamaan Islam. Mengapa hal ini bisa terjadi? Dan bagaimana desain pembelajaran keagamaan islam yang baik? Selama ini metode pembelajaran keagamaan Islam yang digunakan masih dengan penyajian yang lebih lebih banyak dititik beratkan pada rangsangan dengan (auditory) berupa latihan (drii), pengulangan, sebagian besar waktu disekolah digunakan untuk hal-hal yang memanfaatkan beberapa tingkat berpikir secara konvergen karena praktek harian dan tes disekolah terfokus pada penyerapan konten pelajaran melalui cara menghafal bukan pada proses berpikir untuk menganalisis dan mensintesiskan masalah. ${ }^{1}$ Ini sangat sesuai dengan pola-pola pembelaajaran yang menggunakan otak kiri, dimana anak didik kurang hiperaktir dan kurang mendapatkan banyak mendapatkan rangsangan dalam pembelajaran.

Masalah ini timbul karena dengan berkembangnya budaya teknologi para generasi sekarang, mulai sejak mereka kecil anak sudah diberi rangsangan dengan (auditory) tapi anak tidak mempunyai kemampuan dalam pemecahan masalah, karena dengan pola pembelajaran di sekolah tidak disesuaikan dengan pola pembelajaran yang dibutuhkan oleh anak didik.

Sekolah menjadi tidak sejalan dengan pemikiran peserta didik. Semenara itu pula pendidikan pada umumnya adalah populasi dengan pemikiran pola menggunakan otak kiri, sama seperti pada dominasi otak kiri lainnya. Mempunyai kelemahan atau kesulitan dalam memahami bahawa orang lain mempunya cara pandang yang berbeda dalam hal memproses keadaan.

Orientasi pendidikan kita sampai saat ini masih banyak cenderung pada fungsi otak kiri terutama dalam pembelajaran keagamaan Islam. Sehingga kurang memberi kesempatan untuk berkembang secara proporsional pada fungsi otak kanan. Hal ini

\footnotetext{
${ }^{1}$ David A. Sousa,(2012) Bagaimana Otak Belajar, Edisi Ke-IV (Jakarta, PT Indeks).hlm. 295
} 
terjadi karena pembelajaran di sekolah masih cenderung mementingkan target pencapaian kurikulum dibandingkan dengan penghayatan terhadap isi kurikulum secara imajinatif dan kreatif. Dan gejala ini masih tampak sejak proses pendidikan Sekolah Dasar (SD) sampai dunia perguruan tinggi. sehingga hal ini tidak memberikan peluang bagi peserta didik untuk berpikir divergen dan non-konvensional.

Padahal terlalu banyak merangsang otak kiri secara berlebihan dan mengindahkan fungsi otak kanan, akan menghasilkan anak yang pandai namun seperti robot atau komputer, namun kehilangan modal sangat berharga dalam kehidupannya dikemudian hari, yaitu pola pikir yang menggunakan kata hati, merangsang kreatifitasnya dan daya imajinasinya bebas tanpa tekanan dan paksaan dari siapapun.

Masih kental sekali budaya pendidikan orang tua atau guru di Negara kita yang berusaha untuk mengarahkan anaknya sesuai dengan keinginan orang tua dan guru. Hal ini sesuai dengan pernyata Suyadi, bahwa orang tua dan guru membesarkan (mengajarkan, mendidik) anak mereka sesuai dengan harapan atau cita-cita orang tua dan gurunya. Salah satu contoh Misalnya, ketika dulu orang tuanya bercita-cita menjadi arsitek tapi dia gagal, maka dia berharap bahwa anaknya-lah yang harus meneruskan atau melanjutkan cita-citanya tersebut.

Dalam dunia pendidikan, paradigma proses pembelajaran bersumber pada peserta didik dan kebijaksanaan dari guru ${ }^{2}$. Dunia pendidikan yang memberikan sentuhan ilmu neurosains dalam implementasi pembelajarannya sudah mengalami banyak perubahan. Karena guru memang dituntut untuk mengubah paradigma masa lalu yang masih cenderung menggunakan pembelajaran secara konvensional kepada manageman guru yang kreatif (Super) dengan metode neurosains.

Namun menjadi guru yang baik, kreatif "Super" tidak mudah? Sebelumnya tidak terbayangkan bahwa untuk menjadi pendidik yang "Super" ada banyak masalah yang harus dikuasai, dipelajari,dan diketahui. Antara lain alasannya sebagai berikut :

1. Gejala-gejala yang diketahui di sekolah

\begin{tabular}{|l|l|l|l|}
\hline a. & Anak malas belajar & i. & Kurang ada motifasi \\
\hline b. & Melangggar disiplin & j. & Mudah terpengaruh negatif \\
\hline c. & Tidak kooperatif & k. & Malas \\
\hline d. & Pelupa & l. & Jenuh/suntuk \\
\hline e. & Bodoh & m. & Masa bodoh \\
\hline f. & Pemalu & n. & Tidak ceria dalam belajar \\
\hline g. & Melawan orang tua & o. & Sensitive \\
\hline h. & Pembolos & p. & Dan sebagainya \\
\hline
\end{tabular}

Tabel 1. Permasalah Anak di Kelas

${ }^{2}$ Mel Silberman, (1996)Active Learning: 101 Strategies to Teach Any Subject (Massachusetts). hlm. 17. 
2. Dengan permasalahan yang ada diatas apa yang seharusnya pendidik lakukan?

\begin{tabular}{|l|l|l|}
\hline Masalah yang dihadapi siswa & No & \multicolumn{1}{|c|}{ Tugas Guru } \\
\hline & a. & Intropeksi \\
& b. & Terus belajar \\
& c. & Terus berlatih \\
d. & Kontinuitas \\
& e. & Mencari terobosan baru \\
& f. & Merubah paradigma lama \\
& g. & Mempelajari ilmu neurosains \\
& h. & \\
\end{tabular}

Tabel. 1.2. Permasalahan Siswa dan Kewajiban Guru

Oleh karena itu kini waktunya kita merubah paradigma kita untuk memasukkan mata pelajaran tentang ilmu akal (neurosains) padas kurikulum lembaga pendidikan terutama pembelajaran keagamaan Islam. Sehingga keberhasilan pembelajaran yang berbasis otak dengan metode pendekatan Quantum Teaching, Quantum Learning dan Brain Based Learning dan lain sebagainya sebagai sumbangan pemikiran neurosains untuk dunia pendidikan. Dalam konteks pendidikan Islam terutama dalam sekala "Sekolah Dasar". kecerdasan merupakan hal pokok dalam pengembangan potensi peserta didik terlebih lagi dalam pembentukan karakter, emosional dan rasionalitasnya, seperti IQ, EQ, SQ, MaQ, dan Multiple Intellegence 3 . Dan untuk menciptakan pertumbuhan peserta didik yang sehat baik secara mental, fisik, social, spiritual dan emosionalnya maka lembaga Pendidikan Islam yang merupakan lembaga pembentukan karakter akhlak mulia secara konkrit. Itupun harus di lakukan oleh orang tua dan pendidikan mulai sejak dini.

Oleh karena itu penting kiranya kita menggunakan salah satu desain metode pembelajaran berbasis otak (neurosains). Maka hendaknya guru perlu memperhatikan satu hal yang sangat penting dalam tubuh manusia yang selama ini kemampuannya dan pemanfaatannya masih kurang dioptimalkan (yaitu otak). Hal ini terjadi karena kurangnya pengetahuan kita terhadap karakteristik otak itu sendiri dan itu memerlukan strategi khusus untuk mengoptimalkan fungsi otak tersebut.

${ }^{3}$ Suyadi, Integrasi Pendidikan Islam dan Neurosains dan Implikasinya Bagi Pendidikan Dasar (PGMI) (Yogyakarta: Jurnal Al-Bidāyah, Vol 4 No. 1, Juni 2011 
Karena menurut Jensen, otak kita dapat menerima pembelajaran secara optimal dalam sebuah lingkungan yang kondusif ${ }^{4}$ Maka tiga skema pembelajaran berbasisi neurosains ini dapat di implementasikan dalam desain metode pembalajaran terutama pembelajaran keagamaan islam yang selama ini lebih dikenal dengan metode konvensionalnya (ceramah). Mungkin tiga skema ini bisa menjadi solusi dalam memberikan metode pembalajaran keagamaan, Yaitu ; pembukaan (pencahayaan pendar, denyut berpikir, seting kelas yang menantang, dll); inti (sink setting/ ambak, ekspositori, diskusi, role play dan assesmen), penutup (enker, dan sejenisnya)

\section{Pembahasan}

\section{Tiga Skema Desain Pembelajaran Berbasis Neurosains}

\section{a. Pembukaan}

a) Pencahayaan

Faktor yang sangat penting juga dalam pembelajaran adalah mendesain pencahayaan ruang belajar. Desain ruangan sekolah yang baik seharusnya mampu memberikan atau meningkatkan efektifitasnya dalam proses belajar- mengajar. Sehingga itu mampu membuat warga sekolah termotifasi dan merasa di terima di lingkungan sekolah tersebut dan merasa nyaman selama proses belajar mengajar berjalan ${ }^{5}$. Standar pencahayaan ruang kelas yang baik di Indonesia adalah sekitar 250-300lux. Sedangkan lampu yang digunakan disarankan lampu yang cahayanya tidak terlalu terang dan tidak terlalu redup sehingga cahayanya dapat menyatu dengan cahaya alami.

Dalam kegiatan proses belajar mengajar Sebuah ruangan akan memiliki fungsi yang maksimal ketika memiliki akses pencahayaan yang memadai. Dengan desain pencahayaan yang memadai, maka bendabenda akan dapat dilihat dengan jelas dan tidak menimbulkan pantulan cahaya sehingga aktivitas belajar mengajar dalam ruang akan berjalan dengan lancar. Namun jika pencahayaannya tidak tepat dapat merusak atmosfir didalam ruangan sehingga akan menimbulkan perasaan kurang nyaman, selain itu juga dampak yang ditimbulkan adalah tekanan secara psikologis terhadap pengguna ruang, baik gangguan penglihatan, dan gangguan kesehatan lainnnya. Oleh sebab itu, intensitas cahaya perlu diperhatikan dengan baik agar menghasilkan kesesuaian kebutuhan penglihatan di dalam ruang berdasarkan jenis aktivitasnya. Seperti untuk Laboratorium, Perpustkaan, Ruang kelas, studio dan lain sebagainya karena

${ }^{4}$ Eric Jensen, (2008) Brain-based Learning: Pembelajaran Berbasis Kemampuan Otak, (cet. I; Yogyakarta: Pustaka Belajar), hlm. 11

${ }^{5}$ Bradford Perkins. (2001)Elementary and Secondary School. (Canada: John Wiley \& Sons, Inc.), hlm. 179 
setiap ruangan mempunyai kebutuhan intensita pencahayaannya yang berbeda-beda ${ }^{6}$

Tabel 1. Pencahayaan yang direkomendasikan untuk sekolah

\begin{tabular}{|c|c|c|c|c|c|}
\hline \multirow[b]{2}{*}{ Nama Ruang } & \multirow{2}{*}{$\begin{array}{l}\text { Pencahayaan } \\
\text { Standar (Lux) }\end{array}$} & \multirow{2}{*}{$\begin{array}{c}\text { Kelompok } \\
\text { Renderasi } \\
\text { Warna }\end{array}$} & \multicolumn{3}{|c|}{ Temperatur warna } \\
\hline & & & $\begin{array}{c}\text { warm white < } \\
3.300 \mathrm{~K}\end{array}$ & $\begin{array}{c}\text { cool white } \\
3.300 \mathrm{~K}-5.300 \mathrm{~K}\end{array}$ & $\begin{array}{c}\text { daylight > } \\
5.300 \mathrm{~K}\end{array}$ \\
\hline \multicolumn{6}{|c|}{ LEMBAGA PENDIDIKAN } \\
\hline Ruangan kelas umum & 250 & 1 atau 2 & & $\sqrt{ }$ & $\sqrt{ }$ \\
\hline Library & 300 & 1 atau 2 & & $\sqrt{ }$ & $\sqrt{ }$ \\
\hline Laboratorium Komp. & 500 & 1 atau 2 & & $\sqrt{ }$ & $\sqrt{ }$ \\
\hline Kantin & 200 & 1 atau 2 & $\sqrt{ }$ & $\sqrt{ }$ & \\
\hline
\end{tabular}

Tabel, 1.3. perencanaan pencahayaan ruangan belajar Sumber (SNI 03-6197-2000). ${ }^{7}$

\section{Syarat Pencahayaan yang baik}

Sumber pencahayaan yang baik adalah dengan intensitas yang tidak menyilaukan, merata, tidak berkedip-kedip, menyebar dan tidak menimbulkan pantulan atau bayangan pada objek tertentu dan intensitasnya harus diukur dengan beban aktivitas belajar mengajar. Ketika kita menerima cahaya atau objek maka mata menerima kemudian (otak) memproses. Sinar cahaya yang dipantulkan atau diteruskan dari suatu objek yang mempunyai keterangan yang dapat dilihat, menstimulasi "elektro chemical" penerima dalam mata dan mengirinkan sinyal ke otak yang kemudian menghasilkan suatu sensasi penglihatan.

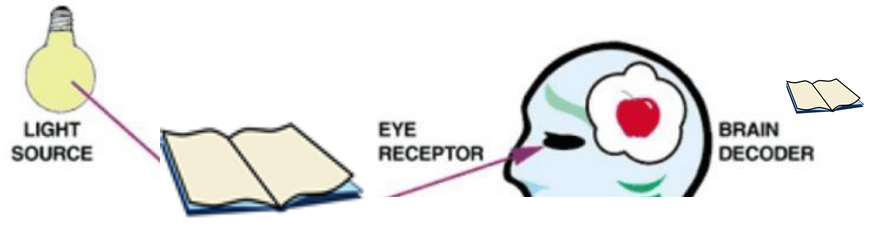

Perlu diperhatikan oleh kita juga, mata sangat mudah lelah bila terjadi perbedaan intensitas penerangan yang terlalu besar antara bidang kerja benda disekitarnya, karena mata kita akan memerlukan banyak daya yang besar untuk bisa beradaptasi dengan kondisi tersebut. Maka untuk mendapatkan hasil penerangan yang merata dan baik, kita harus mempertimbangkan iluminasi sudut penyinaran lampu, jarak penempatan dan jenis lampu yang diperlukan harus sesuai dengan beban aktivitas yang ada dalam ruangan atau fungsi ruang tersebut.

\section{b) Denyut Berpikir}

Yang dimaksud dengan denyut berpkir disini mengambil dari istilah wartawan. Bahwa pada tahap ini guru menyediakan sebuah musik yang

\footnotetext{
${ }^{6}$ Harten, P.Van dan Ir.E.Setiawan..(1985) Instalasi Listrik, Arus Kuat2. (Bandung : Binacipta). hlm. $36-42$

${ }^{7}$ SNI 03-6197-2000: Konservasi Energi Sistem Pencahayaan pada Bangunan Gedung.
} 
diperdengarkan kepada siswa. Pemutara musik pada tahap ini bukan sekedar untuk hiburan. Namun Menurut De Porter dan Henarcki mereka mengungkapkan.

"dengan menggunakan musik khusus baik klasik atau (musik murottal), anda dapat membantu mengerjakan tugas mental yang melelahkan sambil relaks dan konsentrasi, karena seiring dengan denyut nadi dan juga tekanan darah menurun, gelombang otak kita melambat dan otototot menjadi relaks. ${ }^{8}$

Musik dipahami oleh Budilinggo diartikan sebagai ilmu pengetahuan dan seni tentang kombinasi titik dari nada-nada atau irama baik vocal maupun instrumental. Musik meliputi harmoni dan melodi. Sebagai perwujudan ide-ide dan emosi yang tidak hanya tersusun atas tempo, dinamika warna, ritmis suara dan unsur-unsur lainnya namun juga musik memiliki suatu makna. Didalam berbagai literatur, musik memiliki kekuatan untuk meningkatkan kemampuan berpikir seseorang dan juga bisa mengobati penyuakit. Maka Ketika musik diterapkan menjadi sebuah obat terapi, musik dapat memulihkan, meningkatkan atau memelihara kesehatan mental, fisik, spiritual dan emosi.. Hal ini disebabkan musik mempunyai bebarapa kelebihan, karena musik bersifat membuat orang rileks, nyaman, damai. Karena perlu diingat bahwa banyak dari proses dalam hidup kita selalu berirama, sebagai contoh, detak jantung, detak nadi, nafas kita, dan itu semuanya berulang dengan irama.9

Terapi alternatif dalam pengobatan khususnya yang berkaitan dengan saraf otak manusia pernah diterapkan memalui musik. Pada awal abad ke- 20 "Eva Vescelius" pernah menjadi salah satu figur yang paling berperan dalam terapi musik. Banyak tulisannya yang dipublikasikan berkaitan dengan terapi musik. Ia mempercayai bahwa objek dari terapi musik adalah melakukan harmonisasi atau penyelarasan terhadap seseorang melalui osilasi atau lebih tepatnya vibras.

Menurut David A. Sousa, ${ }^{10}$ Memperdengarkan musik di dalam kelas kepada siswa semua tingkat, dapat mendorong mereka tetap focus dan produktif. Harus diingat bahwa tidak ada satu pun jenis musik ataupun volume yang tepat bagi semua orang, karena setiap orang memiliki kecenderungan musik tersendiri. Jadi pastikan bahwa musik yang dimainkan benar-benar musik yang berpengaruh baik, bukan musik yang mengganggu suasana dan tugas-tugas kelas.

\footnotetext{
${ }^{8}$ DePorter, Bobbi \& Hernacki, Mike. (2016), Quantum Learning: Membiaasakan Belajar Nyaman \& Menyenangkan. (Bandung: PT.Mizah Pustaka). hlm. 73

9 Budilinggo, (1993) Bentuk dan Analisis Musik. (Jakarta Depdikbud)

${ }^{10}$ David A. Sousa, (2012), Bagaimana Otak Belajar, edisi ke 4 (Jakarta utara, PT. Indeks, 2012). hlm, 280
} 
Musik bisa diperdengarkan pada waktu yang berbeda selama episode pembelajaran berlangsung. Pastikan memilih musik yang sesuai dengan aktivitas yang dikerjakan. Musik dapat diperdenarkan pada waktu:

- Sebelum pelajaran dimulai (pilih musik yang membangkitkan semangat)

- Saat aktivitas yang melibatkan gerakan tubuh (pilih nada-nada gembeira)

- Saat siswa mengerjakan tugas-tugas tertulis, baik sendiri atau berkelompok (pilih musik yang mempermudah pembelajaran, atau

- Pada akhir jam pelajaran (siswa mendapatkan kesan-kesan positif, menunggu pembelajaran episode berikutnya.

Namun ada hal yang perlu kita pertimbangkan dalam memperdengarkan musik adalah Perhatikan jumlah ketukan per menit . karena musik berpengaruh terhadap kecepatan detak jantung, tekanan darah, dan kondisi emosional, sangat penting guru memperhatikan ketukan (beat) yang permenit pada musik. Jika musik ditujukan untuk mempermudah proses pembelajran siswa, pilih musik dengan rata-rata 60 ketukan per menti(sama dengan rata-rata detak jantung). Jika musik diperdengarkan untuk aktivitas-aktivitas berkecepatan tinggi, maka pilih musik dengan ketukan 80 - 90 permenit. Utuk menenangkan kelompok siswa yang rebut, misalnya di kantin sekolah atau area-area yang umum, pilih musik dengan ketukan antara 40 - 50 ketuk per menit.

\section{c) Setting Kelas yang Menantang}

Sebagai biologis yang lain, otak anak juga berkembang secara alami dan memerlukan asupan gizi untuk dapat bekerja dengan optimal. Karena itu, orang tua dan guru juga bertanggung jawab memantau kecukupan gizi anak. menjaga kondisi biologisnya dari berbagai ancaman, dan memberikan tugas-tugas yang sesuai dengan tahap perkembangan otak anak. system kerja lobus-lobus di dalam celebri korteks telah memberikan pemahaman bahwa pembelajaran aktif, menyenangkan dan berpusat pada siswa sangat baik dalam mengaktivasi otak siswa. Sehingga potensi anak berkembang dengan optimal. Sebaliknya, pembelajaran yang pasif, menegangkan dan membosankan akan membuat anak jeuuh dan cepat lupa. Dari beberapa riset yang dilakukan oleh para ahli menjelaskan bahwa pembelajan harus dapat mendorong anak untuk aktif melakukan berbagai hal yang sesuai dengan tahap perkembangannya. ${ }^{11}$

Hasil riset dalam educational neurosains telah menginspirasi praktisi pendidikan dalam mengembangkan pendekatan yang memfasilitasi otak agar bekerja dengan optimal, yaitu Quantum Teaching, Brains Base Learning dan Quantum Learning dan sejenisnya (belajar berbasis kemampuan otak).

${ }^{11}$ Khiyarusoleh, U. (20126), Konsep Dasar Perkembangan Kognitif pada Anak, Menurut Jean Piaget. DIALEKTIKA (Jurnal Pemikiran dan Penelitian Pendidikan Dasar, 2016) 5(1), 1-10. 
Pendekatan ini dengan mempertimbangkan bagaimana otak dipengaruhi oleh pengalaman dan lingkungannya yang sifatnya alami bagi otak sehingga proses pembelajaran tidak memaksa siswa untuk belajar, tetapi mendorong siswa untuk belajar dengan sendirinya. ${ }^{12}$ Jangan terlalu sering siswa diberi jawaban utuk dihafalkan lagi, tapi berikan mereka masalah untuk dipecahkan sehingga Suasana kelas akan lebih hidup dan lebih menantang rangsangan otaknya untuk berpikir.

Syafa'at dalam penejelasan lestari mengungkapkan bahwa pendekatan pembelajaran berbasis otak menawarkan konsep orientasi pembelajarannya pada upaya pemberdayaan otak peserta didik dengan cara menciptakan suasana belajar yang mendorong siswa untuk aktif, menantang, menyenangkan, dan bermakna bagi kehidupan siswa. ${ }^{13}$

Berikan mereka materi dengan pertanyaan-pertanyaan yang memerlukan berpikir tingkat tinggi, contohnya :

- Siapakah Nabi kedua puluh lima?

- Apakah persamaan-persamaan dan perbedaan-perbedaan antara perang uhud dan perang badar?

Setiap pertanyaan diatas mengharuskan kita berpikir, namun tipe berpikir yang digunakan untuk setiap pertanyaan tidak sama. Pertanyaan pertama dapat dijawab cukup dengan mengingat daftar yang ada di dalam memori jangka panjang. Perntanyaan kedua dijawab dengan cara yang berbeda. Pertama kita harus mengingat apa saja yang pernah kita ketahui tentang kedua perang tersebut, kemudian memisahkannya dalam daftar yang berbeda dilanjut dengan menganalisisnya untuk menntukan peristiwa mana saja yang sama dan mana yang berbeda.

Dua pertanyaan di atas memerlukan proses berpikir yang berbeda dan meningkat lebih kompleks untuk pertanyaan berikutnya, sehingga sampai pada jawaban yang dapat diterima. Contoh ini menunjukkan bahwa sebagian cara berpikir lebih kompleks dibandingkan cara berpikir lainnya. Pemindaian otak menunujukkan bahwa berbagai bagian berbeda dari otak, khususnya korteks frontal, turut terlibat pada saat tugas - tugas memecahkan masalah menjadi lebih sulit. ${ }^{14}$

12 Latifah, R. A., \& Mahmudi, A. (20128), Pengarub Pembelajaran Matematika dengan Pendekatan Brain Based Learning terhadap Kemampuan Penalaran Matematis Siswa SMP pada Materi Teorema Pythagoras. (Jurnal Pendidikan Matematika-S1,), 7(2), 58-66

13 Lestari, K. E. . (2014) Implementasi BrainBased Learning untuk meningkatkan kemampuan koneksi dan kemampuan berpikir kritis serta motivasi belajar siswa SMP. JUDIKA (Jurnal Pendidikan UNSIKA,2014), 2(1), 36-4

14 Cole, M.W., Basic, A,. Kass, R,. \& Schneider, W. Prefrontal Dynamics Underlying rapid instructed task learning revers with practice. The Jurnal of Neuroscience, 30 (42) 14245-14254 


\section{b. Inti Pembelajaran}

\section{a. Sink Setting atau AMBAK}

Pada tahap ini guru menciptakan rangsangan keingintahuan dan kesenangan atau mengatur kondisi antisipatif dalam hal ini guru bisa mengkaitkan dengan kehidupan sehari-hari. AMBAK merupakan singkatan dari "Apa Manfaatnya BagiKu”. Sebelum pendidikan memulai beberapa aktivitas belajar, maka kita disarankan untuk mengajukan pertanyaan pada diri sendiri peserta didik, "Apa Manfaatnya BagiKu?”.

Segala aktifitas dalam pembelajaran harus mempunyai nilai manfaat pribadi, jika tidak, maka peserta didik akan merasa tidak mempunya motifasi dalam mengikuti pembelajarannya. Motivasi untuk melakukan hal yang diperoleh dari latihan mental ini maka disebut AMBAK. ${ }^{15}$

Menurut De Potter \& Hernacki $^{16}$, AMBAK merupakan motivasi yang peserta didik dapat dari pemilihan secara mental antara manfaat apa dan akibatnya dari keputusan yang dilakukan. Motivasi ini sangat diperlukan dalam kegiatan belajar mengajar karena dengan adanya motivasi maka keinginan untuk belajar para peserta didik akan selalu ada. Pada langkah ini guru akan memberikan penjelasan tentang manfaat yang didapat setelah mempelajari materi tersebut.

Misalnya , guru menjelaskan tentang materi sopan santun atau akblak "dalam beberapa decade ini masyarakat indonesia mulai kehilangan jati dirinya karena ini merupakan salab satu dampak dari globalisasi; satu contoh kebudayaan di Indonesia adalah gotong royong, yang saat ini mulai luntur digantikan dengan budaya 'individualis'. Contoh kebudayaan lainnya adalah budaya sopan santun, yang sudah mulai luntur juga di kalangan masyarakat terutama remaja. Padahal negara kita adalah negara yang menjunjung tinggi sopan santun, dan budaya sopan santun itu sangatlah penting.

Tatakrama atau lebih sering disebut sopan santun seharusnya dilakukan, dengan siapapun, kapanpun, dimanapun dan dalam kondisi seperti apapun. Sekali pun kita memiliki jabatan yang tingg atau orang yang punya tanggungjawab yang lebih dari pada orang lain, maka kita harus tetap saja sopan dengan siapapun. Nomor satu itu adalah attitud. Percuma kalau kita punya status pendidikan tinggi, pangkat yang tinggi namun tidak mempunyai attitude yang tinggi. Sama saja tidak ada gunanya. Bukankah alasan kita berpendidikan tinggi agar kita lebih tahu tentang banyak hal kebaikan. ! Kita tidak akan pernah dihargai orang lain jika kita tidak pernah menghargai orang lain. Maka oleh karena itu kita boleh memilih untuk menjadi siapa karena kita mempunya hak prerogratif terbadap diri kita tapi kita sebagai makbluk social ada tata cara yang

15 Hamruni, (2009)strategi dan model-model pembelajaran aktif menyenangkan. Yokyakarta: UIN Sunan Kalijaga, 2009, hlm. 53

16 De Poprter \& Hernacki, (2001),Quantum Learning, Membiasakan Belakajar Nyaman dan Menyenangkan (Ner Work. Khaifa, 2001). hlm. 49 
harus kita perhatikan dalam beragaul atan bermasyarakat. ${ }^{17}$ karena Menurut de porter \& Hernacki. Apakah itu masuk akal atau tidak, apakah itu lebih baik atau tidak bagi kamu, yang penting alternatif yang lebih menarik adalah alternatif yang kamu pilih.

Maka dalam tahap ini guru berusaha untuk menumbuhkan, yaitu Menumbuhkan minat, menyertakan diri siswa, berusaha memikat mereka, dan memuaskan dengan AMBAK (apakah manfaatnya bagiku). ${ }^{18}$

\section{b. Ekspositori}

Metode ekspsitori menurut Sanjaya. ${ }^{19}$ Ialah merupakan desain metode pengajaran yang lebih menekankan kepada suatu proses penyampaian materi secara verbal dari seorang pendidik kepada kelompok peserta didik dengan tujuan agar peserta didik dapat dengan mudah mengusai materi yang disampaikan secara optimal (teacher centered approach). Menurut Dimyati, ${ }^{20}$ adalah memindahkan keterampilan, dan nilai-nilai pengetahuan kepada peserta didik. Sedangkan menurut Haduyo, ${ }^{21}$ adalah bisa meliputi gabungan metode driil, Tanya jawab, metode penemuan, metode peragaan dan metode ceramah.

Dengan kata lain bahwa stretegi ekspositori merupakan strategi yang sangat menekankan pada penyampaian materi secara verbal dari seorang guru kepada peserta didiknya dengan maksud agar siswa lebih cepat menangkap mareri pembelajaran secara sempurna atau lebih optimal. Dan dalam strategi ini guru menyampaikan langsung materi pelajarannya dan siswa tidak dituntut untuk menemukan materi tersebut. Karena strategi ekspositoriini lebih menekankan kepada proses bertutur, maka seringkali ekspositori ini disebut juga strategi "chalk and talk"

\section{Langkah-langkah Strategi Pembelajaran Ekspositori}

Menurut Gurusinga dan Sibrani. 22 langkah-langkah untuk menerapkan Strategi Pembelajaran Ekspositori antara lain :

1) Persiapan merupakan kunci awal dari Strategi pembelajaran Ekspositori adalah.

a) Menggugah dan berusaha untuk menggugah rasa ingin tahunya siswa

b) Menggugah dan merangsang rasa ingin tahunya siswa

${ }^{17}$ Bobbi Deporter \& mike Hernacki, (2011), Quantum Learning, (Bandung: Kaifa,), hlm. 46

18 Bobbi Deporter \& mike Hernacki, (2011), Quantum Learning....... hlm. 10

19 Sanjaya, W. (2008). Strategi Pembelajaran. (Bandung: Kencana Prenada Media Group,). Hlm. 179

${ }^{20}$ Dimyati dan Mudjiono. (1999). Belajar dan Pembelajaran. (Jakarta: Rineka Cipta). Hlm. 172

21 Hudoyo, H. (1998). Mengajar Belajar Matematika. (Jakarta: Depdikbud. 133). Hlm. 133

22 Gurusinga dan Sibarani, 2011. Penerapan Strategi Pembelajaran EkspositoriUntuk Meningkatkan Hasil BelajarSiswa Fakultas Teknik UniversitasSatya Negara Indonesia, 2 (4), 29-31. 
c) Menciptakan suasana atau iklim pembelajaran yang menyenangkan bagi siswa agar siswa merasa tertarik dengan situasi belajar.

2) Penyajian merupakan langkah penyampaian materi pelajaran dari guru kepada siswa atau kelompok siswa yang sesuai dengan persiapan yang telah dilakukan dari awal.

3) Korelasi merupakan hubungan antara materi pelajaran dengan pengalaman hidupnya siswa atau hal-hal yang bisa memungkinkan siswa dapat menangkap hubungannya dengan materi yang disampaikan dengan pengalaman yang dimilikinya.

4) Menyimpulkan untuk memahami inti dari materi yang telah didapat siswa atau yang telah dipaparkan oleh guru. Agar siswa dapat mengambil intisari dari proses pemaparan dan memberikan keyakinan kepada siswa bahwa yang dipaparkan itu merupakan suatu kebenaran.

5) Mengamplikasikan merupakan langkah yang sangat penting dalam semua strategi pembelajaran karena dengan ini guru dapat mengumpulkan informasi tentang penguasaan siswa terhadap materi yang telah disampaikan. Dan untuk mengetahui hal ini adalah dengan teknik memberikan tes sesuai materi yang telah disampaikan atau dipaparkan.

\section{c. Diskusi}

Menurut Suryosubroto. ${ }^{23}$ Metode diskusi merupakan cara penyajian materi pelajaran dimana guru memberikan kesempatan atau ruang untuk mengadakan perbincangan guna mengumpulkan suatu pendapat dan membuat kesimpulan dengan menyusun berbagai alternative pemacahan terhadap masalah yang ada. Sedangkan Zain. ${ }^{24}$ menyebutkan tahapan yang harus dilalui dalam metode diskusi adalah :

1) Merumuskan suatu masalah dengan jelas

2) Guru membentuk kelompok-kelompok diskusi dengan terlebih dahulu memilih pimpinan diskusi sebagai leader untuk mengatur ruangan kelas, kursi, sarana dan lain sebagainya sesuai dengan tema dan tujuan diskusi yang ada.

3) Siswa diberikan arahan dan pengawasan oleh guru dalam menjalankan.

4) Pendidik memberikan motivasi agar siswa mau bekerja.

5) Materi diskusi harus dikerjakan oleh semua anggota kelompok tidak boleh dikerjakan oleh satu orang saja.

${ }^{23}$ Suryosubroto, (2009), Proses Belajar Mengajar di Sekolah.( Jakarta: PT Rineka Cipta. 2009). Hlm. hlm. 86

24 Zaini, Hisyam, (2008), Strategi pembelajaran Aktif, (Yogyakarta, Pustaka Insan Maadani). 
6) Seluruh siswa mencatat dan menyusunnya secara sistematis kemudian salah satu perwakilan kelompok menyampaikan didepan kelas.

Dilihat dari pesertanya. Menurut Sudjana. ${ }^{25}$ Diskusi dapat dibedakan menjadi dua :

1. Ada yang terdiri atas beberapa orang saja (kelompok), contohnya, diskusi kelas, debat dan sejenisnya.

2. Ada yang melibatkan banyak orang sehingga disebut metode interaksi massa, contohnya forum, workshop, seminar dan sejenisnya.

Yang perlu diperhatikan dalam metode diskusi adalah :

1. Sebuah perencanaan dan persiapan yang matang

a. Tujuan dari diskusi harus jelas

b. Persyaratan peserta diskusi harus memenuhi ketentuan yang ada. Dan jumlah peserta diskusi harus disesuaikan dengan sifat diskusi tersebut.

c. Penentuan masalah yang akan didiskusikan harus sejelas mungkin.

d. Waktu dan tempat harus jadi bahan pertimbangan juga.

2. Pelaksanaan diskusi

a. Buat struktur kelompok yang terdiri dari (pimpinan diskusi, sekretaris, anggota

b. Bagi tugas dalam diskusi

c. Merangsang partisipasi siswa

d. Mencatat hasil rapat dari ide dan saran-saran yang ada

e. Menghargai pendapat atau ide dari semua anggota diskusi

f. Berusaha menciptakan suasana yang menyenangkan

3. Tindak lanjut

a. Merangkum hasil diskusi

b. Dibacakan kembali untuk mengkoreksi kekurangan dari hasil diskusi.

c. Membuat penilaian terhadap hasil diskusi sebagai pertimbangan dan perbaikan untuk diskusi berikutnya .

4. Faktor yang mempengaruhi keberhasilan diskusi.

a. Kepandaian pemimpin diskusi dalam memimpin berjalannya diskusi

b. Jelasnya tujuan dari masalah yang dirumuskan

c. Mengusahakan agar cukup problematik sehingga itu merangsangan daya piker peserta diskusi. Hal ini bisa dirumuskan dengan bentuk pertanyaan.

25 Sudjan, N (2010) Dasar-Dasar Proses Belajar Mengajar. (Bandung: Sinar Baru Algensindo). hlm. 80 
d. Partisipasi aktif dari semua anggota diskusi

e. Adanya ransangan dalam jalannua diskusi

\section{d. Role Play}

a) Pengertian Role Play

Desain pembelajaran yang berdasarkan pengalaman yang menyenangkan salah satunya role play (permainan peran). Metode role play adalah dengan cara penguasaan materi pembelajaran melalui pengembangan imajnasi peserta didik. Salah satu proses belajar yang tergolong dalam metode simulasi ada di dalam metode role play ini. ${ }^{26}$ Ada beberapa hal yang penting untuk kita perhatikan dalam pelaksanaan metode bermain peran ini yaitu menentukan topic, pembuatan lembar kerja, anggota peran dan perlunya latihan singkat tentang dialog dan pelaksanaannya. ${ }^{27}$

Pengalaman belajar yang bisa kita dapat dari metode permainan peran ini adalah: komunikatif, kerjasama dan mampu menginterpresentasikan suatu kejadian secara langsung. Melalui permainan peran ini siswa mampu mengeksplor hubungan-hubungan antara manusia dengan cara mendiskusikannya, sehingga secara bersama-sama para siswa mampu mengeksplore nilai-nilai, sikap, perasaan-perasaan dan berbagai strategi dalam memecahkan masalah. ${ }^{28}$

Dapat kita simpulkan dari beberapa pendapat yang ada diatas bahwa metode role play merupakan suatu metode pembelajaran yang didalamnya yang terlihat adanya perilaku pura-pura dari peserta didik atau peniruan karakter, sifat atau perilaku dari tokoh-tokoh sejarah sedemikian rupa atau memerankan suatu keadaan tentang kebiasaan masyarakat baik itu ditinjau dari nilai positifnya (protagonist) maupun dari segi positifnya (antagonis). Dengan demikian metode ini bisa dibilang metode yang melibatkan para peserta didik untuk berpurapura memainkan suatu peran tokoh yang terlibat dalam proses sejarah dan lain sebagainya.

b) Langkah-langkah Pembelajaran Menggunakan Metode Role Play Prosedur teknis yang bisa digunakan dalam metode ini adalah $:^{29}$

a. Buatlah sebuah kisah atau topik dimana pendidik akan mendemonstrasikan perilaku yang harus dilakukan. (contohnya (mendemonstrasikan materi tentang sejarah perang Uhud yang memerankan keadaan nabi dan para

26 Mulyono, (2012), Strategi Pembelajaran, (Malang: UIN Maliki Press, 2012), 44

27 Syaiful Bahri Djamarah, (2005), Guru Dan Anak Didik Dalam Interaksi Edukatif, (Jakarta: PT Rineka Cipta,), hlm. 237

28 Syaiful Bahri Djamarah, (2005), Guru Dan Anak Didik Dalam Interaksi Edukatif ....238

${ }^{29}$ Syaiful Bahri Djamarah, (2005), Guru Dan Anak Didik Dalam Interaksi Edukatif .....238 
sahabatnya atau bisa materi Ibadah tentang balasan bagi pelaku orang yang suka shodaqoh dan sebagainya).

b. Sampaikan kepada peserta didik bahwa guru akan memainkan peran sebagai peran utama dalam permainan peran ini. Dan peserta didik tugasnya membantu guru untuk menjadi pemeran pembantu dalam peran ini.

c. Minta kepada siswa untuk memerankan karakter orang lain. Dan guru memberikan siswa sebuah pembukaan agar diapat dibaca oleh siswa guna memantu pendidik memahami peran yang dimainkan.

d. Permainan peran ini terus dilakukan sampai siswa meningkat dalam memahami perannya agar dia bisa menangani situasi. Hal ini dapat memberikan kemampuan ketika dia memainkan peran yang sebenarnya.

Yang perlu disiapkan dalam memainkan role play di dalam kelas yang perlu kita perhatikan adalah : ${ }^{30}$

\section{1) Instruksi dan persiapan awal}

a. Guru harus mampu memberikan situasi problem yang dipilih bisa menjadi "sosiodrama" yang menfokuskan pada salah satu jenis peran, problem dan situasi familier. Semua ini harus dijelaskan mulai dari deskripsinya, siswa-siswa yang terlibat, keadaan peristiwanya, dan posisi-posisi awal yang harus dijalankan oleh pelaku khusus.

b. Siswa diberi pemanasan sebelum memulai bermain peran ini, dan diminta di ikuti oleh semua siswa. Hal ini dilakukan untuk menyiapkan siswa dan membantu siswa dalam mengembangkan imagnasinya agar terbentuk kekompakan dalam kelompoknya dan terjadi interaksi yang baik dalam permainan ini. Salah satunya bisa.

c. Pada tahap ini guru memberikan arahan secara khusus pada semua pemain setelah kita memeberikan penejalasan pembukaan kepada seluruh anggota kelas. Penjelasan ini meliputi larar belakang dan karakter-karakter yang paling mendasar baik melalui tulisan atau lisan. Para pemeran dipilih secara sukarela. Siswa kita berikan kebebasan untuk memilih peran yang disukai atau sesuai dengan situasi yang pernah mereka alami. Siswa diberikan kesempatan untuk menunjukkan pengalaman yang pernah alam. Dalam brifing, pemeran diberikan deskripsi secara rinci, tentang perasaan, kepribadian

30 Oemar Hamalik. (2007), Proses belajara mengajar (Jakara: PT Bumi aksara, 2007) 215-217 
dan keyakinan dari karakter yang akan diperankan. Hal gunanya untuk membangun masa lampau dari karakter tersebut. Dengan ini kita dapat merancang ruangan dan peralatan yang perlu digunakan dalam bermain peran tersebut.

d. Para pemeran diberikan instruksi agar saling berhubungan dengan masing-masing peran kepada audien. Audien diusahakan ikut berperan secara aktif dalam permainan ini. Untuk itu maka kelas bida dibagi menjadi dua kelompok. Yang satu sebagai kelompok pengamat dan yang kedua sebagai kelompok speculator, semuanya harus melaksanakn fungsinya masing-masing: kelompok pertama sebagai pengamat dan bertugas mengamati : 1) perasaan karakter individu, 2) karakter khsus yang diinginkan dalam situasi ini dan 3) mengapa karekter merespon atas cara yang mereka lakukan. Kelompok Kedua sebagai speculator yang bertugas menanggapi bermain peran ini dari tujuan dan analisis pendapat. Tugas kelompok ini adalah mengamati garis besar serangkaian tindakan yang dilakukan oleh karakter-karekter khusus ini.

2) Tindakan Dramatik dan Diskusi

a) Audien berpartisipasi dalam penugasan awal kepada pemeran dan para actor terus melakukan perannya selama situasi permainan berlangsung

b) Jika terdapat tingkah laku yang menuntut untuk dihentikannya permainan maka permainan harus berhenti pada titik-titik penting tersebut.

c) Seluruh peserta di kelas selanjutnya ikut partisipasi dalam kegiatan diskusi yang memusat pada sebuah situasi permainan ini. Setiap kelompok audien diberikan waktu menyampaikan hasil observasinya dan reaksinya. Para actor juga dilibatkan dalam diskusi tersebut. Guru membimbing dengan maksud agar berkembang pemahaman para siswa tentang pelaksanaan bermain peran serta berefek langsung menumbuhkan pemahaman baru yang berguna untuk merespon dan mengamati situasi yang lain dalam kehidupan sehari-hari.

\section{e. Assesment}

Assesmen digunakan untuk menetapkan dan menentukan dimana letak suatu masalah yang dihadapi dan apa yang menjadi kebutuhan siswa dalam belajar saat ini. Karena assesmen berfungsi untuk melihat kesukaran dan kemampuan yang di hadapi oleh peserta didik. Ini sebagai bahan untuk menentukan apa sebetulnya yang di inginkan dalam pembelajarannya. 
Assesmen sangat berhubungan erat dengan evaluasi pada siswa. Karena evaluasi merupakan bagian pokok dalam metode pembelajaran yang bisa memberikan keuntungan bagi siswa dan guru. Evaluasi bagi guru adalah alat untuk mengetahui apakah pelajaran yang disampaikan dapat diterima oleh siswa dengan baik, untuk mengetahi rekam apa yang telah di capai oleh siswa, begitu juga untuk membantu siswa dalam belajarnya. Dan bagi siswa evaluasi adalah suatu umpan balik tentang kekurangan dan kelebihan yang dimiliki sehingga mampu memotivasi siswa dalam meningkatkan kemampuan belajarnya agar lebih berprestasi lagi. Cara yang dapat dilakukan untuk melaksanakan evaluasi ini adalah:

a. Memberikan evaluasi yang memberikan umpan balik terhadap hasil kerja siswa.

b. Melaksanakan evaluasi yang adil dan objektif serta menyampaikan kepada siswa hasil evaluasi dari kerjanya kepada siswa.

c. Berikan kesempatan siswa untuk mengevaluasi terhadap dirinya sendiri.

d. Berikan kesempatan siswa untuk mengadakan evaluasi terhadap temannya.

\section{Penutup}

\section{a. Senam otak}

Salah satu metode yang baik untuk menunjang perkembangan akademiknya dan non akademiknya siswa adalah senam otak, senam otak dapat meningkatkan kemampuan belajar dan mengaktifkan otak, sehingga meningkatkan daya ingat dan konsentrasi apalagi selama beberapa jam anak belajar sudah jenuh dalam menerima pelajaran jadi anak butuh dibuat rileks agar apa yang di terima bisa masuk dalam memori otak jangka panjangnya.

Manfaaat dari senam otak ini banyak sekali bagi perkembangan kemampuan akademik dan non akademik pada anak diantaranya yaitu senam otak yang dapat mengaktifkan otak untuk meningkatnya kemampuan anak dalam belajar serta konsentrasi meningkatkan dan daya ingat, dan merelaksasi kan otot-otot kita yang tegang... ${ }^{31}$ Menurut Fanny, senam otak memberikan mamafaat atas stimulus dan rangsangan kepada otak sehingga kemampuan konnitifnya meningkat. Serta control emosi juga meningkat. ${ }^{32}$

31 Paul E, Dennison \& Gail E Dennison (2002). Buku Panduan Lengkap Senam Otak. Jakarta: Gramedia) hlm. 19-30

32 Febryana Arief D (2014). Pengaruh brain Gym Terhadap Peningkatan Keseimbangan Pasien Strok non Hemoragik. Diakses dari http://eprintd.ums.ac.id/32440/11/11/01\%20NASKAH\%PUBLIKASI.pdf. Pada tgl 7 Januari 2019, jam 10.11 WIB 
Dennison memberikan pendapat. ${ }^{33}$ Bahwa senam otak memberikan manfaat yang laur biasa diantaranya :

a. Mampu mengoptimalkan fungsi setiap bagian dalam otak, siswa mendapatkan stimulus terhadap kegiatan belajar siswa sehingga mampu memanfaatkan seluruh kemampuan otak.

b. Bagi siswa yang mendapatkan hambatan dalam belajarnya senam otak ini sangat efektif dalam mengoptimalkan fungsi otak siswa, jika siswa mampu mengoptimalkan fungsi otaknya maka itu dapat memudahkan siswa dalam berkonsentrasi, rileks dalam belajarnya serta mampu berpikir yang luas.

Salah satu contoh yang mungkin bisa dilakukan oleh guru dalam senam otak adalah dengan metode gerakan diagonal. Salah satu gerakan otak yang bisa dilakukan adalah dengan metode Gerak Diagonal (Cross Crawl)

Tubuh melakukan gerakan secara terkordinasi, ketika salah satu kaki bergerak maka tangan yang berlawanan melakukan gerakan pada saat yang sama. Gerakan badan kesamping, kedepan, kebelakang dan mengarahkan mata kesemua arah. Gerakan ini efektif untuk meransang otak siswa dalam menerima informasi. Gerakan ini mampu meningkatkan koordinasi tubuh kanan dan kiri, memperbaiki stamina, menyeimbangkan emosi dan meningkatkan koordinasi pendengaran dan penglihatan.

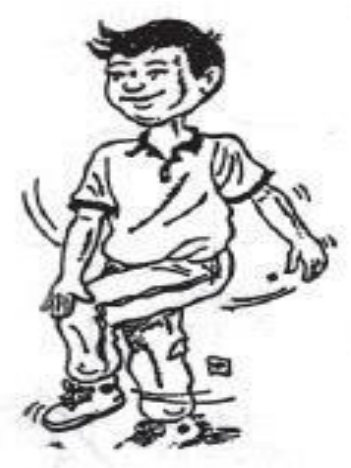

Gambar 1. Gerak Diagonal

Sumber: Gambar ini disadur dari: Titi S Sularyo dan Setyo

Handryastuti. ${ }^{34}$

Dengan metode ini siswa yang mengalami kejenuhan, capek dan tidak bersemangat karena terlalu banyak diberikan materi selama seharian akan kembali menemukan rasa semangatnya dan menghilangkan rasa stresnya. 2006)

33 Paul E Dennison. Brain Gym: (2006), Senam Otak. Buku Panduan Lengkap (Jakarta: Grasindo,

34 Setyo Handryastuti \& Titi S. Sularso (2002). Senam otak. Diakses dari http://saripediatri.idai.or.id/ pdfile/ 4-1-8.pdf. pada tanggal 6 Januari 2019, Jam 07.22 WIB

AL-MURABBI: Jutnal Studi Kependidikan dan Keislaman - Vol 6, No. 1 (2019) 


\section{Catatan Akhir}

Suatu anugerah terbesar yang diberikan oleh Allah kepada manusia adalah otak untuk berpikir namun selama ini otak kita kurang masksimal dalam penggunaannya karena banyak manusia yang belum memahami tentang ilmu otak itu sendiri. Dan apa yang guru lakukan selama ini dalam proses belajar mengajarnya tidak ada bedanya hanya menyampaikan materi tanpa memikirkan efektifitasnya. Sehingga siswa tidak diberikan ruang untuk mengembangkan kemampuan otaknya karena masalah yang dihadapi adalah guru yang masih memakai metode yang kuna atau konvensional dalam metode mengajarnya.

Maka oleh karena itu, dibutuhkan suatu metode yang mampu merangsang dan memberikan ruang yang seluas-luasnya kepada siswa untuk mengembangkan kemampuannya yaitu dengan metode ilmu otak (Neurosains). Neurosans dapat aplikasikan dalam pembelajaran kegamaan Islam yang selama ini masih terkenal dengan metode menghafalnya, ceramah dan sejenisnya. Dengan desain pembelajaran keagamaan yang berbasis neurosain ini bertujuan agar kita mengetahui preferensi kecerdasan para siswa mulai dari perilaku, kemampuan belajar dan emosionalnya.

Dalam pembelajaran neurosains merupakan suplemen dari kurikulum yang ada. Metode yang menarik untuk diterapkan apalagi ada koloborasi antara pembelajaran agama Islam dan pembelajaran umum sebagai salah satu basis kemampuan belajar siswa. Maka semoga skema pembelajaran keagamaan yang berbasis neurosains ini mampu memberikan solusi atas sedikitnya pemahaman para guru terhadap karakter atau keinginan para peserta didiknya dalam belajar.

\section{Daftar Rujukan}

Bobbi Deporter \& mike Hernacki, Quantum Learning, Bandung: Kaifa, 2011, Bradford Perkins. (2001) Elementary and Secondary School. (Canada: John Wiley \& Sons, Inc),

Budilinggo, (1993),Bentuk. dan Analisis Musik. (Jakarta Depdikbud)

Cole, M.W., Basic, A, Kass, R,. \& Schneider, W. Prefrontal Dynamics Underlying rapid instructed task learning revers with practice. The Jurnal of Neuroscience, 30 (42) 1424514254

David A. Sousa, (2012), Bagaimana Otak Belajar, Edisi Ke-IV (Jakarta, PT Indeks:)

De Poprter \& Hernacki, (2001), Quantum Learning, Membiasakan Belakajar Nyaman dan Menyenangkan (Ner Work. Khaifa).

DePorter, Bobbi \& Hernacki, Mike. (2016), Quantum Learning: Membiaasakan Belajar Nyaman \& Menyenangkan. (Bandung: PT.Mizah Pustaka).

Dimyati dan Mudjiono. (1999). Belajar dan Pembelajaran. (Jakarta: Rineka Cipta).

Eric Jensen, (2008),Brain-based Learning: Pembelajaran Berbasis Kemampuan Otak, (cet. I; Yogyakarta: Pustaka Belajar, 2008),

Febryana Arief D (2014). Pengaruh brain Gym Terbadap Peningkatan Keseimbangan Pasien Strok non Hemoragik. Diakses dari http://eprintd.ums.ac.id/32440/11/11/01\%20NASKAH\%PUBLIKASI.pdf. Pada tgl 7 Januari 2019, jam 10.11 WIB 
Gurusinga dan Sibarani, 2011. Penerapan Strategi Pembelajaran EkspositoriUntuk Meningkatkan Hasil BelajarSiswa Fakultas Teknik Universitas Satya Negara Indonesia, 2 (4), 29-31.

Hamruni, (2009) strategi dan model-model pembelajaran aktif menyenangkan. Yokyakarta: UIN Sunan Kalijaga,

Harten, P.Van dan Ir.E.Setiawan.(1985). Instalasi Listrik Arus Kuat2. (Bandung : Binacipta.).

Hudoyo, H. (1998). Mengajar Belajar Matematika. (Jakarta: Depdikbud.).

Khiyarusoleh, U. (2016), Konsep Dasar Perkembangan Kognitif pada Anak, Menurut Jean Piaget. DIALEKTIKA (Jurnal Pemikiran dan Penelitian Pendidikan Dasar,) $5(1), 1-10$.

Latifah, R. A., \& Mahmudi, A. (2018), Pengarub Pembelajaran Matematika dengan Pendekatan Brain Based Learning terhadap Kemampuan Penalaran Matematis Siswa SMP pada Materi Teorema Pythagoras. (Jurnal Pendidikan Matematika-S1,), 7(2), 58-66

Lestari, K. E. . Implementasi BrainBased Learning untuk meningkatkan kemampuan koneksi dan kemampuan berpikir kritis serta motivasi belajar siswa SMP. JUDIKA (Jurnal Pendidikan UNSIKA,2014), 2(1), 36-4

Mel Silberman, (1996)Active Learning: 101 Strategies to Teach Any Subject (Massachusetts,).

Mulyono, (2012), Strategi Pembelajaran, (Malang: UIN Maliki Press),

Oemar Hamalik,(2007), Proses Belajar Mengajar (Jakarta: PT Bumi Aksara),

Paul E Dennison. Brain Gym: (2006) Senam Otak. Buku Panduan Lengkap (Jakarta: Grasindo,)

Paul E, Dennison \& Gail E Dennison (2002). Buku Panduan Lengkap Senam Otak. (Jakarta: Gramedia)

Sanjaya, W. (2008). Strategi Pembelajaran. (Bandung: Kencana Prenada Media Group,).

Setyo Handryastuti \& Titi S. Sularso (2002). Senam otak. Diakses dari http://saripediatri.idai.or.id/ pdfile/ 4-1-8.pdf. pada tanggal 6 Januari 2019, Jam $07.22 \mathrm{WIB}$

SNI 03-6197-2000: Konservasi Energi Sistem Pencahayaan pada Bangunan Gedung

Sudjan, N (2010) Dasar-Dasar Proses Belajar Mengajar. (Bandung: Sinar Baru Algensindo).

Suryosubroto, (2009)Proses Belajar Mengajar di Sekolah.(Jakarta: PT Rineka Cipta).

Suyadi, Integrasi Pendidikan Islam dan Neurosains dan Implikasinya Bagi Pendidikan Dasar (PGMI) (Yogyakarta: Jurnal Al-Bidāyah, Vol 4 No. 1, Juni 2011

Syaiful Bahri Djamarah, (2005),Guru Dan Anak Didik Dalam Interaksi Edukatif, (Jakarta: PT Rineka Cipta),

Zaini, Hisyam, 2008, Strategi pembelajaran Aktif, (Yogyakarta, Pustaka Insan Maadani) 